DOI: $10.29202 /$ nvngu/2019-1/10

A. Dekhane ${ }^{1}, \mathrm{PhD}$, W. Tahar ${ }^{2}$, PhD, A. Abderrezak ${ }^{2}$, Dr. Sc. (Tech.)
1 - Ecole Superieure de Technologies Industrielles-ESTIAnnaba, Algeria, e-mail: azzeddine.dekhane@gmail.com

2 - Badji Mokhtar-Annaba University, Algeria

\title{
INVESTIGATIONS AND CONTROL OF THE DC BUS EFFECT FOR ADJUSTING WIND TURBINE POWER
}

Purpose. Renewable energy sources coupled with a rational use of energy can reduce the fossil fuel consumption and, thus, reduce environmental and socioeconomic effects regardless of the energy demand. This study proposes a control of PMW converter scheme for a doubly-fed induction generator at variable speed wind power generation.

Methodology. The research considers three main feeding techniques of DC Bus: 1) ideal continuous (DC) voltage; 2) the use of an uncontrolled rectifier; 3) the use of a PMW controlled rectifier.

Findings. The results show that switching a three-phase inverter in a wind turbine conversion chain is the key to improving the power quality and ensuring maximum participation of the chain in the service-system.

Originality. Surveillance and control of the effect of the DC bus in the objective ensure the active and reactive decoupled power control so that wind turbines are controlled to provide constant active and reactive power during certain periods for contributing to the service system taking into consideration the particular wind speed in Algeria.

Practical value. With the approach suggested, the controlled PMW converter should have wider applications in a great variety of wind power generation using a doubly-fed induction generator.

Keywords: modeling, wind turbine, doubly-fed induction generator, PWM rectifier

Introduction. Wind energy is a clean energy that has been exponentially evolved during the last two decades. Wind energy seems to be an interesting alternative that allows controlling the energy injected into any electrical network. Furthermore, this clean energy is the key to diversifying the energy markets. To be used in numerous applications and respond to economic constraints, the chain of conversion of this energy must be robust and reliable. In fact, this energy should prove better efficiency in the energy market and be achieved which affordable cost. For this end, it is necessary to exploit the maximum wind power. The operating power of the wind depends on the intensity and wind speed, in particular, the speed of the turbine [1].

The used technology for wind energy production had proved its effectiveness on small machines, in which the constant speed operation is directly connected to the mains through a soft start to reduce switching transients. However, up-scaling this technology for large machines is not a straightforward process [2] and still an open subject.

As known, regarding the conversion wind power systems, the doubly-fed induction generator (DFIG) is widely used regarding its several advantages such as: operation at variable speed, four quadrant active and reactive power capabilities, compared with fixed speed induction squirrel cage and synchronous generators, its bidirectional converter is designed to handle about $\pm 25 \%$ of the generator rating, among others [3].

The purpose of this paper is to evaluate different topologies of DC bus configuration. Moreover, we will evaluate the effect of different (DC bus) invertor's input on the control performance of the whole production chain in terms of power.

The structure of the paper is organized as follows: besides this introductory section, section II describes

(C) Dekhane A., Tahar W., Abderrezak A., 2019 the system to be considered, model and rotor current vector control; section III deals with machine modeling; section IV discusses and analyses the obtained results; the last section concludes with a summury.

Description of wind energy system. The below architecture of a wind system (Fig. 1) is the main subject of our study. This architecture is composed of a doubly-fed induction generator (DFIG), a turbine, which through a multiplier drives the DFIG. The DFIG is directly connected to the grid by the stator and also connected through a static three phase converters to rings/brushes system of the machine rotor.

This system operates at variable speed synchronous hypo and hyper. The converter compensates for the difference in mechanical and electrical frequency by injecting a variable current frequency to the rotor.

Modeling of the DFIG. As cited above, we use the DFIG in this study; nowadays, most of the installed wind turbines are based on a doubly-fed induction generator (DFIG), sharing the place with the wound rotor synchronous generators (WRSGs) and the permanent magnet synchronous generators (PMSGs). These generator choices allow variable speed generation [4].

The DFIG is operable as a motor or generator independently of the rotation speed. It allows access to the

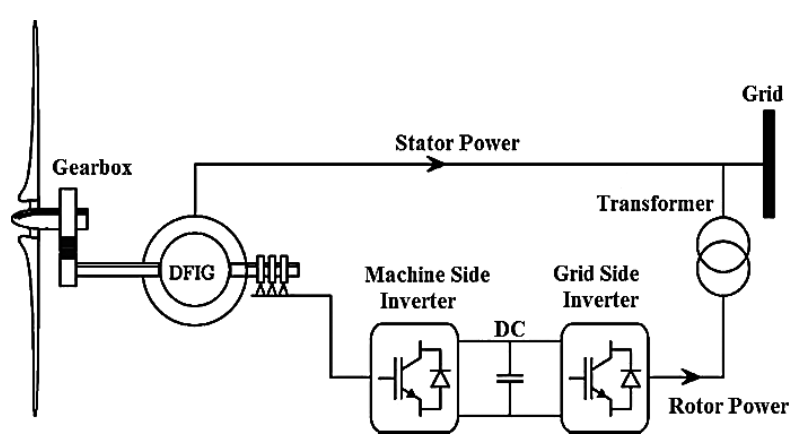

Fig. 1. Chain of conversion 
rotor voltages and currents. The rotor voltage control gives the machine the ability to operate in super or sub synchronism of both motor and generator mode.

The general equations of the DFIG can be written in a three-phase landmark as a result. The generalized reduced order machine model was developed based on conditions and assumptions cited [5]

$$
\left[\begin{array}{l}
{\left[V_{s}\right]} \\
{\left[V_{r}\right]}
\end{array}\right]=\left[\begin{array}{l}
{\left[R_{s}\right]\left[I_{S}\right]} \\
{\left[R_{R}\right]\left[I_{r}\right]}
\end{array}\right]+\frac{d}{d t}\left[\begin{array}{l}
{\left[\varphi_{s}\right]} \\
{\left[\varphi_{r}\right]}
\end{array}\right] .
$$

And the flux

$$
\begin{gathered}
\left\{\begin{array}{l}
{\left[\varphi_{s}\right]=L_{s}\left[I_{s}\right]+M\left[I_{r}\right] .} \\
{\left[\varphi_{r}\right]=M\left[I_{s}\right]+L_{r}\left[I_{r}\right]}
\end{array}\right. \\
L_{s}=I_{s}-M_{s} ; \quad L_{r}=I_{r}-M_{r} ; \quad M=\frac{3 M_{s r}}{2} .
\end{gathered}
$$

Taking into account (2), Park transformations applied to (3) provide

$$
\begin{aligned}
& \left\{\begin{array}{l}
V_{s d}=R_{s} I_{s d}+\frac{d \varphi_{s d}}{d t}-\dot{\theta}_{s} \varphi_{s q} \\
V_{s q}=R_{s} I_{s q}+\frac{d \varphi_{s q}}{d t}-\dot{\theta}_{s} \varphi_{s d} \\
V_{r d}=R_{r} I_{r d}+\frac{d \varphi_{r d}}{d t}-\dot{\theta}_{r} \varphi_{r q} \\
V_{r q}=R_{r} I_{r q}+\frac{d \varphi_{r q}}{d t}-\dot{\theta}_{r} \varphi_{r d}
\end{array}\right. \\
& \left\{\begin{array}{l}
\varphi_{s d}=L_{s} I_{s d}+M I_{r q} \\
\varphi_{s q}=L_{s} I_{s q}+M I_{r q} \\
\varphi_{r d}=L_{r} I_{r d}+M I_{s d} \\
\varphi_{r q}=L_{r} I_{r q}+M I_{s q}
\end{array} .\right.
\end{aligned}
$$

Power expression can be rewritten as follows

$$
\left\{\begin{array}{l}
P=-V_{s} \frac{M}{L_{s}} I_{r q} \\
Q=-V_{s} \frac{M}{L_{s}} I_{r d}+\frac{V_{s}^{2}}{L_{s} \omega_{s}}
\end{array} .\right.
$$

Fig. 2, presents the block diagram of DFIG used in simulation. The inputs are rotor voltages $\left(V_{r d}\right.$ and $\left.V_{r q}\right)$ however, the outputs are the stator active and reactive power $\left(P_{s}\right.$ and $\left.Q_{s}\right)$.

Table 1 shows the main parameters of the induction generator which is used in this study.

Simulations and discussions. We have tested three cases of feeding. To prove this, we consider, in the first place, a perfectly continuous supply, and then we consider it obtained from the output of an uncontrolled rectifier. Finally, we analyze the output of the controlled rectifier; the three cases will be simulated and interpreted.

Ideal case. In this case we consider that the DC bus voltage is perfectly continuous and unchanging through time. It is topped up at the input of variable-speed drive (voltage inverter) feeding the generator side machine (Fig. 1).

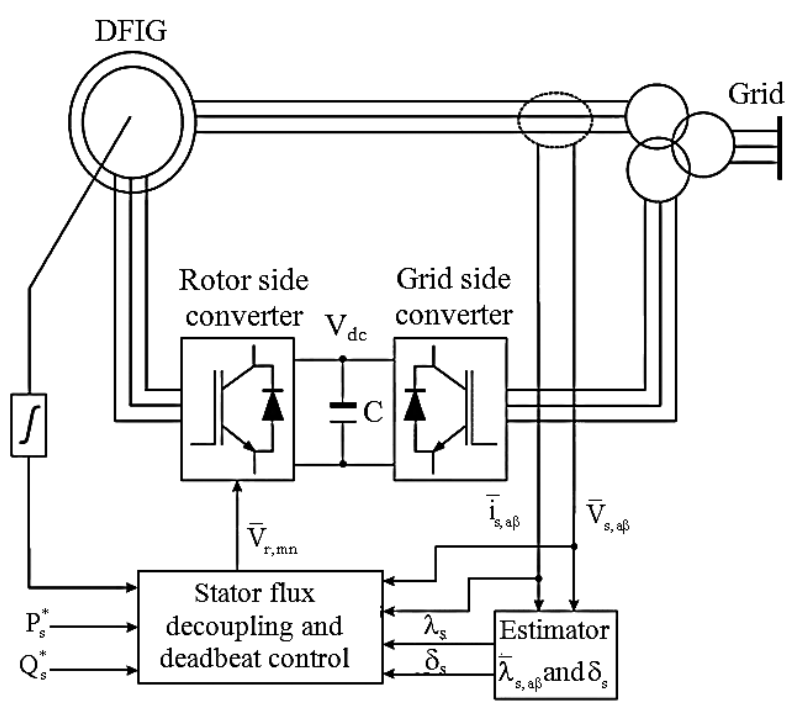

Fig. 2. DFIG bock diagram

Table 1

DFIG parameters

\begin{tabular}{|c|c|}
\hline Components & Rating Values \\
\hline$R_{s}$ & $0.455 \Omega$ \\
\hline$L s$ & $0.07 \mathrm{H}$ \\
\hline$R r$ & $0.19 \Omega$ \\
\hline$L r$ & $0.0213 \mathrm{H}$ \\
\hline$M$ & $0.034 \mathrm{H}$ \\
\hline$P$ & 2 Pole pair \\
\hline
\end{tabular}

We note that the variation of active power does not affect the set of reactive power which stays null.

Case of a non-controlled rectifier. This time, we consider a non-controlled rectifier fed by the alternative grid of the DFIG stator, supplied according to a judicious control at the opening and closing of semi-conductors, a DC voltage at the input of the inverter feeding the rotor of the DFIG.

In this case, we remark the oscillatory shape of the supply voltage. In addition, when changing the active power, decoupling between active and reactive power was lost. Indeed, neither active nor reactive power follows their references.

Case of a controlled PWM rectifier. We will control the six switches in a synchronous PWM control voltages on grid voltage [6]. From the three voltages, we get three sinusoids that will serve as references. Starting from these three references, we can modulate a triangular signal with a high frequency to determine levels of switches command.

In this way, the switches are controlled so that the current in each phase follows the evolution of the fundamental tension. On each leg of the inverter, a switch allows the current to grow and the other to decrease it. The modulation of references sinusoids keeps the currents in sinusoidal envelopes.

To adjust the average value of DC voltage, we vary the amplitude of the modulating signal which varies the modulation index $m$, defined by 


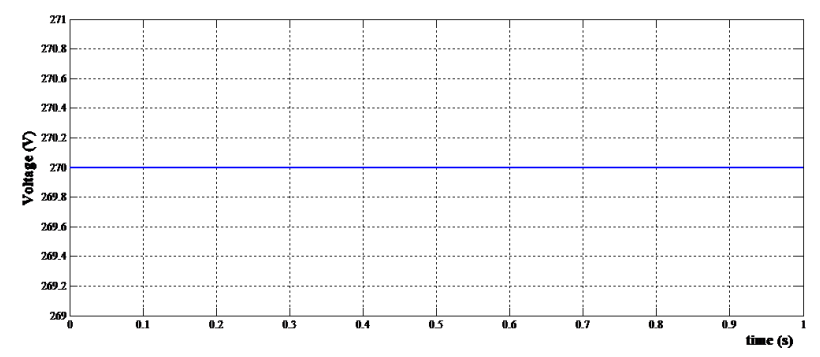

$a$
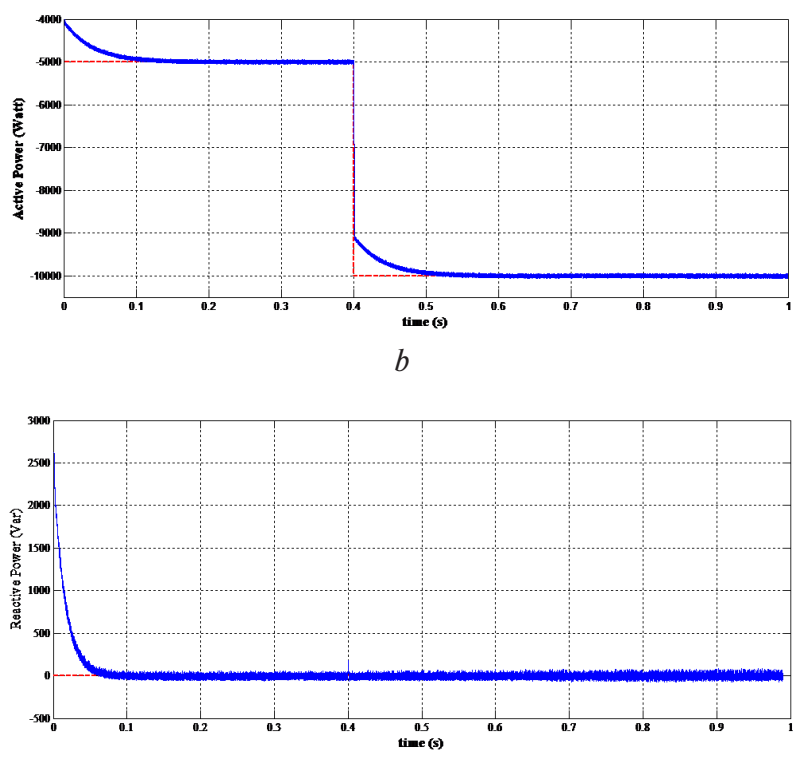

$c$

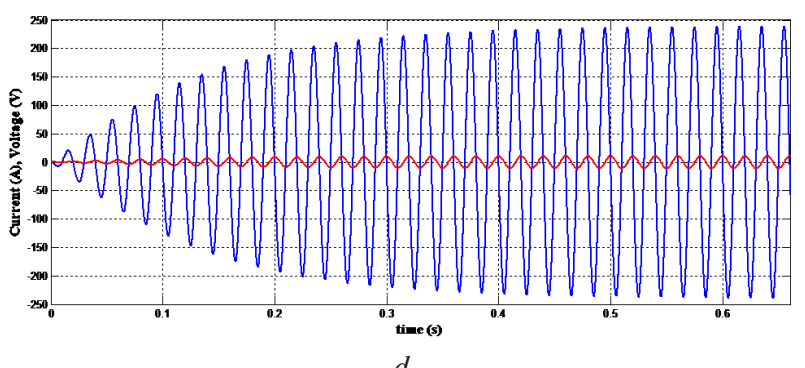

Fig. 3. DC-voltage (a), power (b) reactive power (c), current (red) and stator voltage (blue) in phase A (d)

$$
m=\frac{\text { sine amplitude }}{\text { amplitude triangle }} .
$$

And the voltages are then expressed by

$$
U_{d c}=\frac{\sqrt{2} V_{e f f}}{m} .
$$

As the modulation index is less than 1 so that the triangular signal cuts the sinusoidal signal, we applied a voltage booster rectifier a DC voltage greater than the maximum simple voltage $\sqrt{2} V_{\text {eff }}$. To control the rectifier, these reference voltages are compared with a high frequency triangular modulation signal to generate the PWM control signals of switches. The value of the DC bus voltage is controlled by the amplitude of the modulating signal. This amplitude is established through a PI

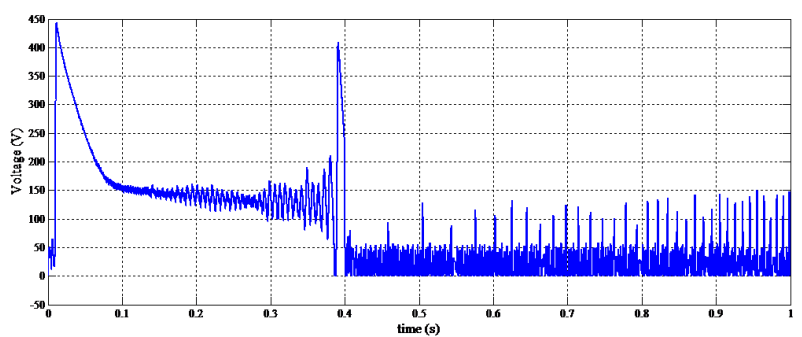

$a$

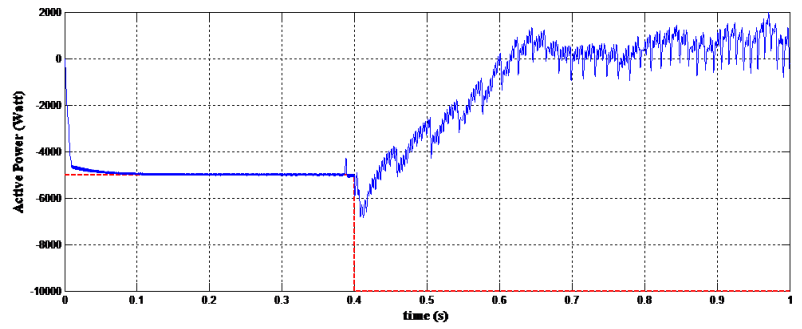

b

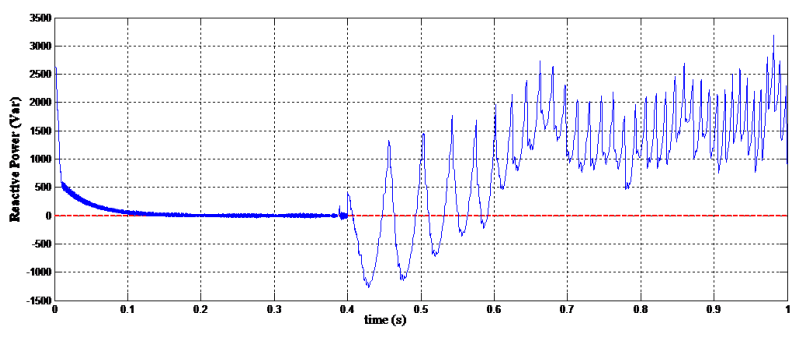

c

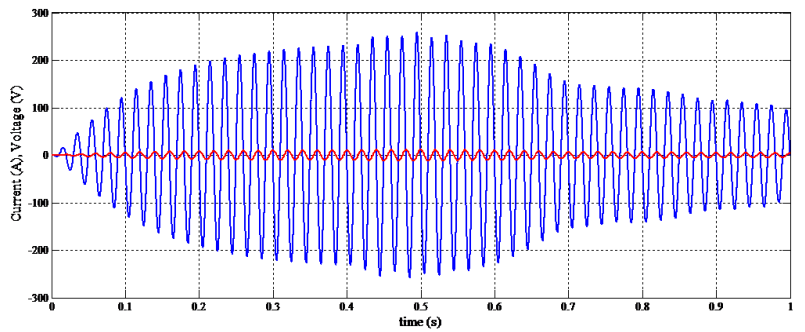

d

Fig. 4. DC-voltage (a), power (b), reactive power (c), current (red) and stator voltage (blue) in phase A (d)

controller based on the error between the set point and the voltage value measured across the capacitor connected to the rectifier.

The block diagram of Fig. 5 summarizes the control principle of such a rectifier.

In addition to the PWM control of the rectifier, we considered the adjustment of the rectified voltage to the input of the inverter to keep it constant. In this order, we planned a loop that basically comprises a voltage sensor, a PI controller and the reference [7].

The simulation of the whole (Fig. 5) shows, unlike the previous result, the voltage is constant and it has kept its value.

Also, the active and reactive powers follow perfectly their respective set points.

Conclusion. Based on the results, it can be concluded that the findings of our research are quite convincing, 


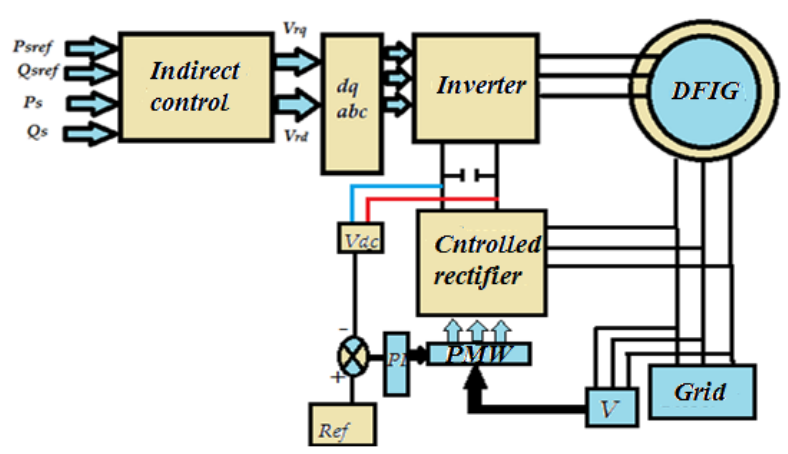

Fig. 5. Block scheme of a PWM rectifier integrated wind turbine system

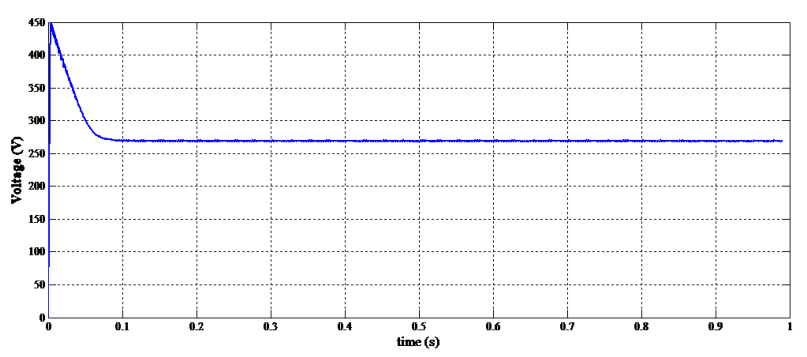

$a$

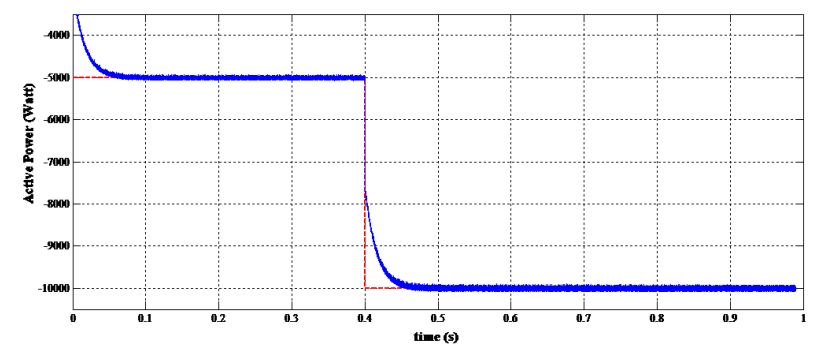

$b$

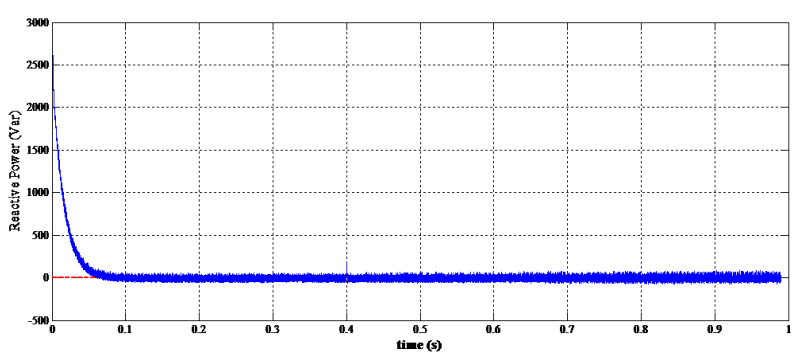

$c$

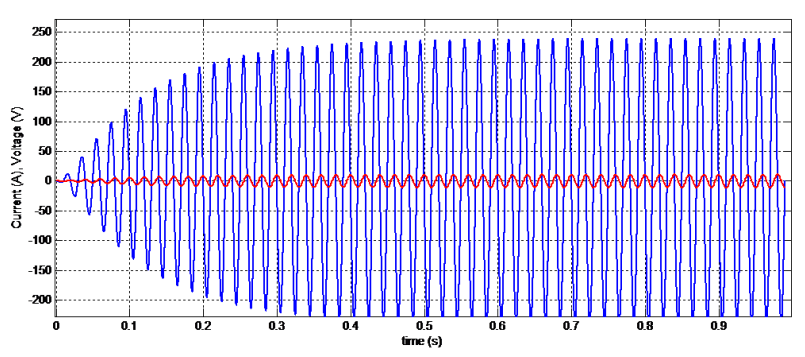

d

Fig. 6. DC-Voltage (a), power (b), reactive power (c), current (red) and stator voltage (blue) in phase $A(d)$ and, thus, the following conclusions can be drawn: we had, in the first place, approved the mathematical model of a doubly fed induction generator by simulation. For this we applied the separate control powers. We considered three cases of feeding, an ideal continuous (DC) voltage, the second in the output of an uncontrolled rectifier and, finally, the last exit of a controlled rectifier in the voltage where the voltage output is ensured by a reference value. We note that the latter gives the desired performance, by cons, for a non-controlled rectifier performance degrades with the loss of decoupling of active and reactive powers.

The simulation results confirm the theoretical effectiveness and the robustness of the PMW controller converter in several operating conditions and variation of parameters.

The findings suggest that this approach could also be useful for wider applications in a great variety of wind power generation using DFIG. Further study of the issue is still required.

\section{References.}

1. Dekhane, A., Lekhchine, S., Bahi, T., Ghoudelbourg, S. and Merabet, H., 2012. DFIG Modeling and Control in a Wind Energy Conversion System. In: IEEE Conference: 'First international conference on renewable Energies and Vehicular Technologies. DOI: 10.1109/REVET.2012.6195285.

2. Himri, Y.A., Rehman, S. B., Himri, S. C., Mohammadi, K. D., Sahin, B. E. and Malik, A. S. F., 2016. Investigation of wind resources in Timimoun region, Algeria. Wind Engineering, 40(3), pp. 250-260.

3. Mohseni, M., Islam, S. and Masoum, M. A. S., 2011. Enhanced hysteresisbased current regulators in vector control of DFIG wind turbines. Power Electronics, IEEE Trans., 26(1), pp. 223-234. DOI: 10.1109/ TPEL.2010.2058816.

4. Kamal, E., M. Oueidat, A. Aitouche and R. Ghorbani, 2013. Robust scheduler fuzzy controller of dfig wind energy systems. Sustainable Energy, IEEE Trans., 4(3), pp. 706-715. DOI: 10.1109/TSTE.2013.2242500. 5. Chowdhury, B. H. and Chellapilla, S., 2006. Doublefed induction generator control for variable speed wind power generation. Electric Power Systems Research, 76, pp. 786-800. DOI: 10.1109/ICMA.2009.5246281.

6. Yao, J., Li, H., Chen, Z., Xia X. and Chen, X., 2013. Enhanced control of a DFIG-based wind-power generation system with series grid-side converter under unbalanced grid voltage conditions. Power Electronics, IEEE Trans., 28(7), pp. 3167-3181. DOI: 10.1109/ TPEL.2012.2219884.

\section{Дослідження та контроль впливу шини постійного струму для регулювання потужності вітряної турбіни}

\section{А. Дехане ${ }^{1}$, В. Тахар $^{2}$, А. Абдерразака ${ }^{2}$}

1 - Університет Аннаба, м. Аннаба, Алжир, e-mail: azzeddine.dekhane@gmail.com

2 - Університет Баджи Мохтар, м. Аннаба, Алжир 
Мета. Поновлювані джерела енергії в поєднанні з раціональним використанням енергії можуть знизити споживання викопного палива й, таким чином, зменшити екологічні та соціально-економічні наслідки незалежно від потреби в енергії. У цьому дослідженні пропонується управління схемою перетворювача PWM для асинхронного генератора 3 подвійним живленням при регулюванні швидкості вітрогенератора.

Методика. У дослідженні були розглянуті три основні методи живлення шини постійного струму: 1) ідеальна постійна напруга; 2) використання некерованого випрямляча; 3) використання PMWкерованого випрямляча.

Результати. Результати показують, що включення трифазного інвертора в ланцюжок перетворення енергії вітряних турбін є ключем до поліпшення якості електроенергії та забезпечення максимальної участі ланцюга в системі обслуговування.

Наукова новизна. Спостереження й контроль впливу шини постійного струму в установці забезпечує регулювання активної та реактивної незв'язної потужності, завдяки чому вітрові турбіни контролюються для забезпечення активної та реактивної потужності в певні періоди для більшого сприяння системі обслуговування, ураховуючи особливу швидкість вітру в Алжирі.

Практична значимість. При пропонованому підході регульований $\mathrm{PMW-перетворювач} \mathrm{матиме}$ ширшу сферу застосування в різноманітних установках вітрогенерації з використанням асинхронного генератора подвійного живлення.

Ключові слова: моделювання, вітрова турбіна, асинхронний генератор подвійного живлення, РWMвипрямляч

\section{Исследование и контроль влияния шины постоянного тока для регулирования мощности ветряной турбины}

1 - Университет Аннаба, г. Аннаба, Алжир, e-mail: azzeddine.dekhane@gmail.com

2 - Университет Баджи Мохтар, г. Аннаба, Алжир

Цель. Возобновляемые источники энергии в сочетании с рациональным использованием энергии могут снизить потребление ископаемого топлива и, таким образом, уменьшить экологические и социально-экономические последствия независимо от потребности в энергии. В этом исследовании предлагается управление схемой преобразователя РWM для асинхронного генератора с двойным питанием при регулировании скорости ветрогенератора.

Методика. В исследовании были рассмотрены три основных метода питания шины постоянного тока: 1) идеальное постоянное напряжение; 2) использование неуправляемого выпрямителя; 3) использование PMW-управляемого выпрямителя.

Результаты. Результаты показывают, что включение трехфазного инвертора в цепочку преобразования энергии ветряных турбин является ключом к улучшению качества электроэнергии и обеспечению максимального участия цепи в системе обслуживания.

Научная новизна. Наблюдение и контроль влияния шины постоянного тока в установке обеспечивает регулирование активной и реактивной несвязной мощности, благодаря чему ветровые турбины контролируются для обеспечения активной и реактивной мощности в определенные периоды для большего содействия системе обслуживания, учитывая особую скорость ветра в Алжире.

Практическая значимость. При предлагаемом подходе регулируемый PMW-преобразователь будет иметь более широкую сферу применения в разнообразных установках ветрогенерации с использованием асинхронного генератора двойного питания.

Ключевые слова: моделирование, ветровая турбина, асинхронный генератор двойного питания, $P W M-$ выпрямитель

Рекомендовано до публікації Саїд Алем. Дата надходження рукопису 28.08.17. 